\title{
Integrating Technology in Language Class rooms with special focus on Engineering Students: An Analysis
}

\author{
Dr .S. Mercy Gnana Gandhi \\ Sathyabama University
}

\begin{abstract}
Effective tech integration must take place across the curriculum to enhance the learning process. Tech tools offer numerous ways to students to experiment anything they require. No doubt,technology is ubiquitous; stirring almost every part of our lives and our communities. It stands supreme above all and Integrating technology into classroom education leads to teaching and learning of fundamental computer skills and software programs. Presently, active engagement, group participation, frequent feedback and link with realworld experts are the basic amenities of technology education. The innumerable resources of the online world afford each classroom with diverse learning materials. Thus technology changes the methodology of teaching, offering educators useful ways to attain and assess student understanding through multiple means.
\end{abstract}

Keywords: technology, students, computer, integration, teaching, learning

\section{INTRODUCTION}

Today everything has gone completely computerized and with the advent of Cyber Net and Multimedia, scholars go to the extent of teaching through computers and the Web. Nothing is static in the world and everything changes almost every second of the day. Gone are the days when teaching and learning is only relied on chalks and book bags. Recently, there has been a greater awareness of the need for Practice and Training in Technical English among Engineering students as well as teachers. As a teacher of English in technical institutions for nearly twenty years, the author realizes that Engineering students demand not only academic but also communication skills to survive in this dynamic global market. With development of inventions like the internet, the popularity of educational technology is growing day by day and conventional lessons have been transformed into digital lessons with technical tutors. Online classes, file transfer, chatting through social networks, posting data on academic platforms lead to follow the students' overall success. Moreover, students can maintain a flexible agenda that is suitable for them. Audio-visual presentations through multimedia projectors take a major role in improving the delivery of instruction and in increasing the comprehension level of the students. Moreover, touch screen technology makes the teaching -learning process more interactive and interesting.

\section{THE NEED OF THE DAY}

Establishing a harmonious relationship among the teacher, students and subject is a mandatory process, and teaching is an excellent task done by a teacher in the classroom. Successful teaching is not merely imparting awareness and advice to students, but giving a variety of information on various areas. Moreover, effectiveness in teaching does not rely on teacher's age, sex, and teaching experience but on the subject knowledge and communicative skill of the teacher himself. An effective teacher is always an expert in subject matter, rather than understanding the misconceptions of his students that are brought to the classroom. Thus, whenever a chance arises, a teacher needs to get progress on his education and professional qualifications. The present day technology offers the opportunity for teachers to develop into more collaborative and to extend learning beyond the classroom. Educators can generate students learning communities, fellow educators and experts in various disciplines around the world. Such an improved collaboration, enabled by technology offers entrance to instructional resources and materials with to assess their excellence and worthiness.

\section{THERAPY THROUGH TECHNOLOGY}

Language teachers in Engineering colleges find it a little difficult in encouraging and implementing novel practices related to technology whereas their concentration is largely focused on completing the academic curriculum framed by the institution which is to be completed within the stipulated time. The language teachers may also feel painful to give up their traditional roles as language experts. Their broadmindedness such as eagerness to welcome, recognize and reward the students' independent thinking and their new ideas, generates positive classroom climate. The outcome of a teacher's creativity should be more and 
better opportunities actually provided for students to experience and learn. Creativity in teaching is to be judged by the quality of opportunities, which should be provided by a teacher to his pupils and the extent to which it resulted in pupil's creative productions. Creativity in teaching breeds the creativity in learning. Words of gratitude, praise, sympathy or concern and words of love and joy used by the teachers enable many students to progress towards excellence in their own areas of talent. Some teachers find it hard to express words of praise or recognition. Affection, appreciation, sympathy, and recognition should be communicated both verbally and nonverbally so that the students are encouraged and motivated. It has been statistically found that teachers possessing high verbal creativity are more successful in creating positive socio-emotional classroom climate in comparison to the teachers possessing low verbal creativity. Therefore, every possible attempt should be made for enhancing the verbal creativity of the teachers. The investigators suggest the following techniques and approaches to enhance creativity of pre and in-service teachers.

\section{ROLE OF THE EDUCATORS}

Teachers are expected to plan beautiful tasks that are extremely engaging and are relevant to learning through technology, since they have infinite opportunities to opt for and relate technology in numerous ways. To create an attractive and appropriate lesson that requires students to use content knowledge and to apply critical thinking skills, a teacher directs the students to solve a community problem using technology. Students can create an online community forum, public presentation, to their planned solution. Social networking platforms can be used to gather information and suggestions of resources from their contacts. Even multimedia formats such as videos and blogs may be drafted and be presented. Such work can be shared through virtual discussions with content experts and be stored in online learning portfolios.Moreover, the teachers can take a lead on the assessment and execution of new technologies for learning. With a wide understanding of their own educational technology needs, the teachers can devise short pilot studies to ensure the chosen technology.

\section{NEED TO IMPROVE CURRICULUM}

The objective is not to prepare technocrats but techno-pedagogy, wherein teachers are in a position to integrate technology into teaching learning as well as to develop art and skill of webogogy .So, objectives must be definitely set at skill level on the other hand, professional development of teacher needs to be given much importance. A teacher should have a clear knowledge about the location of proper sites, new and updated softwares and hardwares and their use in teaching -learning process, development of proper pedagogy regarding their content matter by continuous upgradation of content knowledge etc. There must be consequence between academic curriculum and teacher training curriculum so that a teacher can utilize the knowledge of students in designing the teaching learning processes, project works and assignments. Proper care should be taken to provide more practical approach to the curriculum. Approaches to ICT education need to be focussed on providing techno-pedagogy aspect. In addition to the packages being offered like M.S.Office, HTML etc. knowledge about web portals and multimedia software need to be provided as they are user-friendly in developing learning resources. Few of the integration approaches need to be analyzed seriously, so that the students can implement the concept of techno-pedagogy to the maximum level. With the support of the technically trained professionals in this particular field, proper hardware and software needed to develop learning resources can be rightly chosen, according to the requirement. Providing space for a person with necessary knowledge in maintenance of system in organization will provide a incessant availability of technology, up gradation at proper times, and possible and quick help in times of crisis.

\section{FUTURE OF LEARNING}

No doubt, the future of technology in education is cloud computing. The future is about to access, under anywhere learning and collaboration, not only locally but also globally. Teaching-learning process is definitely going to be communal. Schools of the future may have a traditional group of students, as well as online-only students. Technology can never be a barrier to teaching and learning. Schools of the future won't need software installed, servers or local file storage. They demand only a fast robust internet connection. Infrastructure will be paramount to the future of technology in education.

\section{CONCLUSION}

Multimedia Computer Assisted Language Learning is not a case of computer teaching humans, but humans teaching humans through the medium of computer. To do so successfully, we require a thorough understanding of the difficult strengths and weaknesses of both computers and humans and blending them to create a more effective learning environment. Such an attempt has to be carried out systematically and thoroughly, involving the purchase of equipment, redesigning the curriculum and syllabus. For Multimedia Computer Assisted Language Learning to be successful, the existing language teaching structure has to be totally revamped. Such an enormous undertaking requires the support of management, staff and students 
working together and it will determine the ultimate success or failure of implementing Multimedia Computer Assisted Language Learning in any institution. Computers are considered to be good language teachers, if they are used properly. Language teachers continue to ignore technology at their own peril. The aim of the teacher trainers in language teaching is to reform their field to incorporate this powerful tool into the trainee teachers. The computer is neutral. It can as easily be an ally to the language teachers, as it can be rival. Ultimately, the choice is ours. But the time to make the choice may well be running out.

\section{REFERENCES}

[1] Kelm, O. (1992). The use of synchronous computer networks in second language instruction. A Preliminary Report. Foreign Language Annals, 25(5).

[2] Kenning M.-M. \& Kenning M. J. (1990) Computers and language learning: current theory and practice, New York: Ellis Horwood.

[3] Lincolnwood, IL: National Textbook Company (1992). A methodological framework for CALL courseware development.

[4] Martinez-Lage, A. (1997). Hypermedia technology for teaching reading.

[5] Mercy G.Gandhi (2014) The Unprecedented Advances in Interactivity and Multimedia Capabilities in ELT Proceedings of the International Conference on Trends and Innovations in Language Teaching TILT 2014, 14\&15 Nov. 2014, Sathyabama University

[6] Murillp, D. (1991). Maximizing CALL effectiveness in the classroom. CELL Journal, 2(2), 20-25.

[7] Russell, G. Finger, G., and Russell, N. (2000) Information Technology Skills of Australian Teachers:Implications for Teacher Education. Journal of Information Technology for Teacher Education,vol. 9, 2, pp. 149-166.

[8] Thompson, L.W. (2004). Literacy Development for English language learners: Classroom Challenges in the NCLB Age.

[9] Warschauer, M. (1996a). Comparing face-to-face and electronic communication in the second language class room. CALICO Journal, 13(2), 7-26. 